\title{
Hand grip strength in the elderly with upper limbs pain*
}

\author{
Força de preensão palmar em idosos com dor nos membros superiores
}

\author{
Paulo Renato Wagner ${ }^{1}$, Sandro Ascenço ${ }^{1}$, Lia Mara Wibelinger ${ }^{1}$ \\ ${ }^{*}$ Received from the Course of Physiotherapy, University of Passo Fundo, RS, Brazil.
}

\section{ABSTRACT}

BACKGROUND AND OBJECTIVES: Hand grip strength is extremely important to perform daily life activities, such as holding objects, using a handrail or bus supports, carry out domestic tasks, self-care activities, that is, to maintain functionality and independence. This study aimed at evaluating hand grip strength of elderly people with pain in upper limbs.

METHODS: The sample was made up of 119 elderly who were divided by gender, being 19 males and 100 females. General mean age was 67.93 years, mean age of males was 67.58 years and mean age of females was 68 years. The elderly were submitted to evaluation with Kratos dynamometer.

RESULTS: All studied individuals are right-handed and there is a higher prevalence of females. When hand grip strength was compared among genders with no pain, there has been stronger right hand strength and when it was compared between genders with pain, this has influenced the strength of both hands, being muscle strength stronger in males.

CONCLUSION: After analyzing sample results, it was observed that pain has influenced hand grip strength being that male elderly people had stronger muscle strength as compared to females.

Keywords: Elderly, Hand strength, Muscle strength, Pain.

\section{RESUMO}

JUSTIFICATIVA E OBJETIVOS: A força de preensão da mão é de extrema importância na realizaçáo das atividades de vida diária, tais como segurar objetos, utilizar um corrimão ou apoios em ônibus, realizar trabalhos domésticos, atividades de autocuidado, enfim, manter a funcionalidade e independência. O objetivo deste estudo foi avaliar a força de preensão palmar de idosos que apresentam dor em membros superiores.

1. University of Passo Fundo, Course of Physiotherapy, Passo Fundo, RS, Brazil.

Submitted in January 03, 2014.

Accepted for publication in April 25, 2014.

Conflict of interests: none.

Correspondence to:

Lia Mara Wibelinger

Rua Uruguai, 2200

Passo Fundo, RS, Brasil.

E-mail: liafisio@yahoo.com.br

( ) Sociedade Brasileira para o Estudo da Dor
MÉTODOS: A amostra foi composta por 119 idosos, que foram divididos por gênero, sendo 19 homens e 100 mulheres. A média de idade geral foi de 67,93 anos, a média de idade entre os homens foi de 67,58 anos e entre as mulheres foi de 68 anos. Os idosos foram submetidos a uma avaliação com o dinamômetro Kratos .

RESULTADOS: Todos os indivíduos do estudo são destros e há uma maior prevalência de mulheres. Quando é comparada a força de preensão palmar entre os gêneros sem dor, houve uma maior força da máo direita e, quando se comparou entres os gêneros com dor, esta influenciou na força de ambas as mãos, sendo a força muscular dos homens superior.

CONCLUSÃO: Depois da análise dos resultados da amostra estudada, observou-se que a dor influenciou a força de preensão palmar, sendo que os idosos do gênero masculino apresentaram maior força muscular quando comparados ao gênero feminino. Descritores: Dor, Força da mão, Força muscular, Idoso.

\section{INTRODUCTION}

Individuals who have completed 60 years of age are considered elderly in Brazil (Law 10741/2003). Hand grip strength is extremely important to carry out daily activities, such as holding objects, using a handrail or bus supports, carrying out domestic tasks, self-care activities, that is, maintaining different daily activities with autonomy. Studies have identified that hand grip strength has a curvilinear relationship with age ${ }^{1}$.

Traditionally, HGS tests have been used in rehabilitation to evaluate physical fitness of upper limbs (UULL), by measuring the strength of hand and forearm muscles of patients with different upper extremity disorders induced by rheumatoid arthritis, carpal tunnel syndrome, lateral epicondylitis, stroke, traumatic injuries and neuromuscular diseases. HGS measured by dynamometry has good correlation with UULL functional level and general health status, being widely used to select therapeutic procedures and for functional rehabilitation follow-up ${ }^{2}$. Muscle strength in the elderly is a current theme for several studies since it is a major item for their survival and independence for daily activities. There are different measurement methods, as mentioned by Rantanen et al. ${ }^{3}$, which may measure maximum hand grip strength, knee and trunk extension strength.

Valid and reliable HGS evaluation is used to compare the effectiveness of several procedures, to define treatment goals and to evaluate patients' functionality ${ }^{4}$. The tool used to evaluate hand grip is the dynamometer, which measures hand grip strength 
of individuals. In addition to checking hand and upper limbs strength, HGS may be used as indicator of general strength status, thus being used for fitness tests. It also provides a functional integrity index of the upper extremity 5

Some studies have tried to determine normative values for HG performance; however different collection protocols and tools make difficult the generalization of results. In addition, other factors may impair the establishment of universally accepted normative values. Among them there are: gender, age, dominance, evaluation time, body positioning and anthropometric characteristics.

Last, but not least, the adjustment of the size of the handhold used on the hand grip dynamometer is also largely discussed in the literature and it seems that there is the need to adjust the equipment for different hand sizes. Anyway, effort sincerity may depend on several aspects, such as psychological (motivation), the understanding of patients about the meaning of the test, and pain (discomfort caused by the dynamometer), among others. It is recommended that patients are familiar with the dynamometer, that they understand the objective of the test and that verbal and/or visual incentive is used.

Notwithstanding the specialized literature being full of studies using HGS as major study object, there are relatively few studies aiming at gathering and detailing characteristics of the evaluation of such variable, especially with regard to factors intervening with the measurement, and there is no standardization of methods ${ }^{7}$.

In light of such information, this study aimed at evaluating HGS of the elderly with or without UULL pain.

\section{METHODS}

This is a quantitative, descriptive and longitudinal study part of an umbrella project called "Hand Grip Strength in the Elderly".

Sample was made up of 119 elderly, who were divided by gender, being 119 males and 100 females. General mean age was 67.93 years; mean age among males was 67.58 years and among females of 68 years. The elderly were submitted to evaluation with dynamometer Kratos ${ }^{\otimes}$ and, after reading and signing the Free and Informed Consent Term, have agreed to participate in the study.

Statistical package SPSS 18.0 and Windows Microsoft Excel were used for this research. Descriptive statistics, such as mean, standard deviation, variables frequency and percentage and also crossed tables were analyzed. For a better use of data, MannWhitney and Chi-square statistical tests were used being significant $\mathrm{p}<0.05$.

This study was approved by the Research and Ethics Committee (CEP), University of Passo Fundo under number 345.944, in compliance with Resolution CNS 196/96.

\section{RESULTS}

Table 1 shows data regarding sample gender, pain and age. It is observed that all individuals are right-handed, there has been higher prevalence of females, aged between 61 and 70 years being that most part of them had no upper limb pain.

Table 2 shows total sample mean age and mean HGS of left and right hands

Table 3 shows comparison between males and females, without pain, correlating HGS hand grip strength means of right and left hands.

There is only statistically significant difference when right hand is compared between genders.

Table 4 shows comparison between males and females, with pain, correlating mean hand grip strength of right and left hands.

Table 1. Sample characterization

\begin{tabular}{lccc}
\hline Variables & & $\mathrm{n}$ & $\%$ \\
\hline Gender & Female & 100 & 84 \\
& Male & 19 & 16 \\
Pain & With pain & 50 & 42 \\
& No pain & 69 & 58 \\
Age (years) & 60 & 16 & 13,4 \\
& 61 to 70 & 64 & 53,8 \\
& 71 to 80 & 34 & 28,6 \\
Laterality & 81 to 90 & 5 & 4,2 \\
\hline
\end{tabular}

Table 2. Total sample mean hand grip strength and age

\begin{tabular}{lcc}
\hline & Mean & Standard deviation \\
\hline Age (years) & 67.93 & \pm 7.15 \\
Mean right hand & $16.6 \mathrm{~kg}$ & $\pm 6.4 \mathrm{~kg}$ \\
Mean left hand & $15.2 \mathrm{~kg}$ & $\pm 6.1 \mathrm{~kg}$ \\
\hline
\end{tabular}

Table 3. Mean hand grip strength by gender of those without pain.

\begin{tabular}{llcccc}
\hline & Gender & $\mathrm{n}$ & Mean & $\begin{array}{c}\text { Standard } \\
\text { deviation }\end{array}$ & $\mathrm{p}$ value \\
\hline $\begin{array}{l}\text { Mean } \\
\text { right }\end{array}$ & Female & 44 & $14.7 \mathrm{~kg}$ & $4.3 \mathrm{~kg}$ & 0.024 \\
& Male & 6 & $22.2 \mathrm{~kg}$ & $6.6 \mathrm{~kg}$ & \\
Mean left & Female & 44 & $14.0 \mathrm{~kg}$ & $4.8 \mathrm{~kg}$ & 0.640 \\
& Male & 6 & $21.6 \mathrm{~kg}$ & $5.7 \mathrm{~kg}$ & \\
\hline
\end{tabular}

Table 4. Mean hand grip strength by gender of those with pain

\begin{tabular}{llcccc}
\hline & Gender & $\mathrm{n}$ & $\begin{array}{c}\text { Mean } \\
(\mathrm{kg})\end{array}$ & $\begin{array}{c}\text { Standard } \\
\text { deviation }(\mathrm{kg})\end{array}$ & $\mathrm{p}$ value \\
\hline $\begin{array}{l}\text { Mean } \\
\text { right }\end{array}$ & Female & 56 & 15.2 & 5.1 & 0.021 \\
& Male & 13 & 25.4 & 8.5 & \\
Mean left & Female & 56 & 13.5 & 4.9 & 0.032 \\
& Male & 13 & 23.0 & 7.9 & \\
\hline
\end{tabular}


There has been statistically significant difference between genders in both hands of those with pain.

Table 5 compares females with and without pain, correlating HGS means of right and left hands.

Table 5. Mean hand grip strength of females

\begin{tabular}{lllccc}
\hline & Pain & $\mathrm{n}$ & $\begin{array}{c}\text { Mean } \\
(\mathrm{kg})\end{array}$ & $\begin{array}{c}\text { Standard } \\
\text { deviation }(\mathrm{kg})\end{array}$ & $\mathrm{p}$ value \\
\hline Right & Yes & 44 & 14.7 & 4.3 & 0.288 \\
& No & 56 & 15.2 & 5.1 & \\
\multirow{2}{*}{ Left } & Yes & 44 & 14.0 & 4.8 & 0.007 \\
& No & 56 & 13.5 & 4.9 & \\
\hline
\end{tabular}

In comparing means of both hands there is statistically significant difference for the left hand.

Table 6 compares males with and without pain, correlating hand grip strength means of right and left hands.

Table 6. Mean hand grip strength of males

\begin{tabular}{lccccc}
\hline & Pain & $\mathrm{n}$ & Mean & $\begin{array}{c}\text { Standard } \\
\text { deviation }\end{array}$ & p value \\
\hline Right & Yes & 6 & $22.2 \mathrm{~kg}$ & $6.6 \mathrm{~kg}$ & 0.790 \\
& No & 13 & $25.4 \mathrm{~kg}$ & $8.5 \mathrm{~kg}$ & \\
Left & Yes & 6 & $21.6 \mathrm{~kg}$ & $5.7 \mathrm{~kg}$ & 0.682 \\
& No & 13 & $23.0 \mathrm{~kg}$ & $7.9 \mathrm{~kg}$ & \\
\hline
\end{tabular}

It is observed that in males there is no statistically significant difference when both hands are compared.

Table 7 correlates HGS means among different age groups.

Table 7. Mean hand grip strength among different age groups

\begin{tabular}{lcccc}
\hline $\begin{array}{l}\text { Age group } \\
\text { (years) }\end{array}$ & Right $(\mathrm{kg})$ & $\mathrm{p}$ value & Left $(\mathrm{kg})$ & $\mathrm{p} \mathrm{value}$ \\
\hline 60 & $16.4 \pm 8.0$ & 0.416 & $14.8 \pm 7.8$ & 0.793 \\
61 to 70 & $17.3 \pm 6.2$ & & $15.8 \pm 5.9$ & \\
71 to 80 & $15.5 \pm 6.0$ & & $14.3 \pm 6.3$ & \\
81 to 90 & $14.9 \pm 5.5$ & & $14.9 \pm 3.8$ & \\
\hline
\end{tabular}

After analyzing different age groups there have been no statistically significant differences in mean HGS.

\section{DISCUSSION}

After analyzing the sample, it is observed that all individuals are right-handed and there is a higher prevalence of females. When comparing HGS between genders with no pain, there has been more strength of right hand, and when comparing between genders with pain, pain has influence strength of both hands, being males muscle strength higher.

Some studies have shown that hand grip strength is directly proportional to age until 32 years of age and from then on it becomes inversely proportional. It was also observed that males have higher hand grip strength as compared to females ${ }^{4,5,7}$, confirming our study, which has also found higher HGS among males.

Muscle strength tends to be different between genders, being female values below male values. When compared to age, however, strength decreases with aging. There is strong inverse association between HGS and age ${ }^{8}$. A study evaluating 54 individuals of both genders has observed that HGS (Hand Grip Strength) was significantly influenced by demographic and anthropometric variables.

As expected, male HGS was significantly higher as compared to female HGS in all studied age groups both for the dominant and the non-dominant hand. HGS variations between genders have been attributed to body composition differences between males and females. In eutrophic individuals, male and female muscle mass corresponds to approximately $45 \%$ and $30 \%$ of total body mass, respectively. In addition, although the number of muscle fibers is similar between genders, HGS is influenced by the size of muscle fibers which are approximately $15 \%$ smaller for females ${ }^{2,9,10}$.

A different study evaluating HGS and its relationship with functional capacity has also obtained similar results with males presenting higher hand grip strength as compared to females. This is explained by the fact that males have more lean mass by physiological characteristics, justified by higher concentration of testosterone, growth hormone (GH), insulin, which contributes to growth hormone increase (IGF-1), and dehydroepiandrosterone (DHEA), which increases muscle turnover ${ }^{11}$. This is in agreement with our study which has also found weaker HGS among females.

Literature also mention that HGS is correlated to physical strength, cognitive strength and age-related comorbidities, and that males have higher mean HGS values in all stages of life as compared to females. When HGS values are adjusted to age and gender, values are more associated to height, muscle mass and arm muscle area ${ }^{12}$.

A study has evaluated the effects of different maximal strength (Smax) percentages during HGS tests with protocols of one, three and six minutes. In a maximal strength protocol, curve behavior may be explained by an exponential function. They have also shown that at 75 and $50 \%$ of Smax, on the other hand, curve behavior is different, losing its exponential characteristic. For this reason, according to authors, it may not be possible to evaluate hand grip strength fatigue during one minute at 50\% Smax, since strength at this point of the curve may still not be decreasing. They also suggest that in prolonged tests (more than three minutes) hand grip strength performance is affected by intervenient sensory factors such as pain ${ }^{13}$.

A recent study ${ }^{14}$ carried out with general population has shown that, in Portugal, chronic pain affects $54.2 \%$ of people between 60 and 64 years of age, $55.9 \%$ people between 65 and 69 years of age, $65.7 \%$ of people between 70 to 74 years of age and $62.5 \%$ of people above 75 years of age. Results also show that $35 \%$ of people with chronic pain refer moderate to severe incapacity and that pain affects especially domestic responsibilities, leisure and occupational capacity and sleep capacity. However, 
this study does not present pain-related incapacity by age group and does not evaluate the impact of different pain characteristics, such as intensity or duration, on functionality, which is in agreement with our study where, when comparing HGS in both genders, of individuals with upper limb pain, males had higher scores as compared to females, and HGS means were lower for individuals referring pain.

When HGS was compared only among females, it was observed that individuals with pain had higher strength in the left hand. No references in the literature were found confirming our study, when comparing HGS only among female elderly people ${ }^{15}$.

A longitudinal study of 24 years has observed that HGS is a long-term predictor of mortality by all causes, by cardiovascular diseases and of cancer in males 8 .

The importance of evaluating muscle strength along life was discussed in a research which has followed more than 8 thousand males aged between 20 and 80 years in a prospective study and has observed that muscle strength decrease along life is strongly associated to mortality ${ }^{16}$.

Major limitation of evaluating HGS by means of dynamometry is the lack of a cutoff point defining the limit between normality and dysfunction for specific populations. The analysis of reference values presented by previous studies indicates broad variation in HGS data. There are evidences that such variations are a consequence of racial, demographic, anthropometric, social and cultural differences among populations evaluated by different studies. So, to supply more adequate evaluation and follow-up of muscle function, it is important to develop tools able to predict expected HGS values for specific populations ${ }^{2}$.

Different methods have been used to evaluate HGS, being that differences are related to contraction intensity (maximal or submaximal), contraction duration and the number of repetitions (continuous or intermittent). The standardization of evaluation and interpretation methods may allow the development of reliable and universally accepted reference values ${ }^{6}$.

\section{CONCLUSION}

It was observed that pain has influenced HGS and that elderly males had higher muscle strength as compared to females.

\section{REFERENCES}

1. Coelho FG, Gonzaga BT, Costa GA. Avaliaçăo de força de preensão manual em idosos praticantes de musculação. Disponível em: http://www.afrid.faefi.ufu.br/producoes_ cientificas/artigo-51/completo.pdf..

2. Novaes RD, Miranda AS, Silva JO, Tavares BF, Dourado VZ. Equaçôes de referência para a prediçấo da força de preensão manual em brasileiros de meia idade e idosos. Fisioterapia e Pesquisa. 2009;16(3):217-22.

3. Rantanen T, Volpato S, Ferruci L, Heikkinen E, Fried LP, Guralnik JM. Handgrip strength and cause-specific and total mortality in older disabled women: exploring the mechanism. J AmGeriatr Soc. 2003;51(5):636-41.

4. Figueiredo IM, Sampaio RF, Mancini MC, Silva FC, Souza MA. Teste de força de preensấo utilizando o dinamômetro Jamar. Acta Fisiátrica. 2007;14(2):104-10.

5. Moreira D, Álvarez RR, Gogoy JR, Cambraia AN. Abordagem sobre preensão palmar utilizando o dinamômetro JAMAR: uma revisão de literatura. RevBrasCi Mov. 2003;11(2):95-9.

6. Dias JA, Ovando AC, Külkamp W, Borges Junior NG. Força de preensão palmar: métodos de avaliaçāo e fatores que influenciam a medida. RevBrasCineantropom Desempenho Hum. 2010;12(3):209-16

7. Barbosa AR, Souza JM, Lebrão ML, Marucci MF. Relaçấo entre estado nutricional e força de preensão manual em idosos do município de São Paulo, Brasil: dados da pesquisa SABE. Rev Bras CineantropomDesempenho Hum. 2006;8(1):37-44.

8. Gale CR, Martyn CN, Cooper C. Grip strength, body composition, and mortality. Int J Epidemiol. 2007;6(1):228-35.

9. Budziareck MB, Pureza Duarte RR, Barbosa-Silva MC. Reference values and determinants for handgrip strength in healthy subjects. ClinNutr. 2008;27(3):357-62.

10. Stoll T, Huber E, Seifert B, Michel BA, Stucki G. Maximal isometric muscle strength: normative values and gender-specific relation to age. ClinRheumatol. 2000;19(2):10513.

11. Alexandre TS. Relação entre força de preensão manual e dificuldade no desempenho de atividades básicas de vida diária em idosos do município de São Paulo. Saúde Coletiva. 2008;5(24):178-82.

12. Martin FG, Nebuloni CC, Najas MS. Correlaçẫo entre estado nutricional e força de preensão palmar em idosos. Rev Bras GeriatrGerontol. 2012;15(3):493-504.

13. Yamaji S, Demura S, Nagasawa Y, Nakada M. The influence of different target values and measurement times on the decreasing force curve during sustained static gripping work.J PhysiolAnthropol. 2006;25(1):23-8.

14. Azevedo LF, Costa-Pereira A, Mendonça L, Dias CC, Castro-Lopes JM. Epidemiology of chronic pain: a population-based nationwide study on its prevalence, characteristics and associated disability in Portugal. J Pain. 2012;13(8):773-83.

15. Augusto AC, Soares CP, Resende MA, Pereira LS. Avaliaçâo da dor em idosos com doença de Alzheimer: uma revisáo bibliográfica. Textos Envelhecimento. 2004:7(1):89-104.

16. Ruiz JR, Sui X, Lobelo F, Morrow JR Jr, Jackson AW, Sjöström M, et al. Association between muscular strength and mortality in men: prospective cohort study. BMJ. 2008;337-a439. 